\title{
Occurrence of an erythrocytic virus infection in cultured turbot Scophthalmus maximus
}

\author{
Jesús Lamas $^{1, *}$, Catalina Cepeda ${ }^{2}$, Carlos Dopazo ${ }^{2}$, Alicia E. Toranzo ${ }^{2}$, \\ Ramón Anadón ${ }^{1}$, Juan L. Barja ${ }^{2}$ \\ 'Department of Fundamental Biology, ${ }^{2}$ Department of Microbiology and Parasitology, Faculty of Biology, \\ University of Santiago de Compostela, E-15706 Santiago de Compostela, Spain
}

\begin{abstract}
Cytoplasmic inclusions, ranging in slze from 0.3 to $1 \mu \mathrm{m}$, were found in circulating erythrocytes of diseased turbot Scophthalmus maximus (L.), reared on several farms in Galicia (NW Spain). Examination of the erythrocytes with electron microscopy showed virus-like particles within cytoplasmic membrane-bound vacuoles, at the cell membrane or extracellularly. The particles, oval to spherical in shape, displayed a wide range of sizes, from 50 to $160 \mathrm{~nm}$. Particles appeared to be formed at the cell membrane and were released by budding. In negatively stained preparations surface projections or spikes were recognizable on the external envelope. Virological studies carried out in affected turbot allowed the isolation of an enveloped RNA virus from the internal organs. Healthy turbot were infected intraperitoneally with this viral agent tollowed by observation of similar erythrocytic inclusions and virus-like particles $3 \mathrm{wk}$ after infection. Erythrocytes obtained from healthy turbot were infected in vitro. Study of the sequence of morphologic events after virus infection revealed that 5 min after inoculation virus-like particles were observed withın cytoplasmic vacuoles of erythrocytes. Viruslike particles were adsorbed to the cell surface after $30 \mathrm{~min}$ at $0^{\circ} \mathrm{C}$ but not internalized. However, at 4 and at $15^{\circ} \mathrm{C}$ the particles were endocytosed into small vesicles. After 2 to $3 \mathrm{~d}$ at $15^{\circ} \mathrm{C}$, some erythrocytes showed irregular morphology and high electron-dense cytoplasmic areas as well as virus-like particles bring released by budding at the cell membrane. The virus titrations showed that intracellular viral titres were almost constant along the experiment. However, extracellular viral titres increased throughout time reaching maximum values at between 36 and $60 \mathrm{~h}$ post-infection.
\end{abstract}

KEY WORDS: Turbot Scophthalmus maximus Erythrocytic Infection - Virus Ultrastructure Pathology

\section{INTRODUCTION}

Viral infections of fish erythrocytes are characterized by the presence of small inclusions in the cytoplasm. Three intraerythrocytic viruses have been described. The first virus belongs to the family Iridoviridae and includes several probable strains ranging in size from 145 to $360 \mathrm{~nm}$ in diameter which caused viral erythrocytic necrosis (VEN) in a high number of marine fish species (Appy et al. 1976, Evelyn \& Traxler 1978, Reno et al. 1978, Smail \& Egglestone 1980, Meyers et al. 1986). An intraerythrocytic virus of 75 to $100 \mathrm{~nm}$ in diameter causes the erythrocytic inclusion body syndrome (EIBS) in salmonids (Leek 1987, Piacentini et al. 1989, Lunder

•E-mail: bfsuso@usc.es et al. 1990, Foot et al. 1992, Takahashi et al. 1992) and is included in the family Togaviridae (Arakawa et al. 1989). A third uncharacterized intraerythrocytic virus of 80 to $90 \mathrm{~nm}$ in size described in rainbow trout (Pilcher \& Fryer 1980) had some similarities to an erythrocytic virus described in coho salmon (Hedrick et al. 1990) and to virus particles observed in blood cells of Atlantic salmon with the infectious anaemia syndrome (Hovland et al. 1994, Nylund et al. 1995). In Spain, a viral erythrocytic infection in Mediterranean sea bass Dicentrarchus labrax caused by an enveloped RNA virus with reverse transcriptase activity has recently been described (Pintó et al. 1989, 1991). These erythrocytic viruses can be transmitted by injection of blood extracts but, to our knowledge, all attempts to isolate these viruses in cell cultures have failed. 
Very recently, an RNA enveloped virus associated with mortalities in cultured turbot Scophthalmus maximus (L.) has been isolated and identified tentatively as Paramyxovirus-like (Cepeda et al. 1993a, b). In this paper we report that this virus causes a viral erythrocytic infection in those cultured turbot. Additional in vivo and in vitro experimental infections to investigate the morphologic events and replication occurring after viral infection of turbot erythrocytes are also reported.

\section{MATERIALS AND METHODS}

Source of naturally infected fish. Cultured turbot 150 to $500 \mathrm{~g}$ ) from 3 different locations in Galicia (NW Spain) were submitted to our laboratory for histonathological and microbiological studies.

Microbiological analysis. Bacteriological and virological studies were carried out following standard procedures (Thoesen 1994). Samples of spleen, liver, kidney and brain were cultured for viruses on the carp cell line epithelioma papillosum cyprini (EPC) grown in Eagles minimum essential medium supplemented with $5 \%$ foetal calf serum (EMEM-5), 100 IU penicillin and $100 \mu \mathrm{g}$ streptomycin $\mathrm{ml}^{-1}$ (P/S). For bacteriology, samples of the same tissues were plated simultaneously on tryptic soy agar (TSA) with $1.5 \%$ of $\mathrm{NaCl}$ added, and on thiosulfate citrate bile saccharose (TCBS).

Blood smears. After fish were anaesthetized in MS222 (Sigma), blood was collected from the caudal vein in heparinized tubes. Blood smears were air dried, fixed in methanol and stained with May-GrünwaldGiemsa (M-G).

Virus propagation. Isolated viruses used in all experiments were propagated in the EPC fish cell line cultured in EMEM-5 with P/S as described above. The cells were grown in $25 \mathrm{~cm}^{2}$ flasks at $15^{\circ} \mathrm{C}$. When the cytopathic effect became extensive, culture fluids were removed from the flask and centrifuged at $2500 \times g$ for 10 min at $4^{\circ} \mathrm{C}$ to remove cell debris. Supernatants were collected and stored at $-80^{\circ} \mathrm{C}$ until use. Virus titrations were conducted in 96 well microplates containing EPC cell monolayers and the TCID 50 calculated by the method of Reed \& Müench (1938). In addition, infected EPC cell monolayers were dislodged by scraping and processed for transmission electron microscopy (TEM).

Electron microscopy. Blood cells and infected EPC cells examined by TEM were washed twice in phosphate buffered saline and centrifuged. The pellets were fixed in $2 \%$ glutaraldehyde in $0.1 \mathrm{M}$ phosphate buffer and postfixed in $1 \%$ osmium tetroxide in the same buffer, dehydrated and embedded in Spurr's resin. Ultrathin sections stained in uranyl acetate and lead citrate were examined at $80 \mathrm{kV}$ with a Philips CM12 electron microscope equipped with a goniometer
Virus suspensions obtained from EPC cell cultures were negative stained using a $2 \%$ solution of phosphotungstic acid adjusted to $\mathrm{pH} 6.8$ with $\mathrm{NaOH}$. A drop of the staining solution was mixed with a drop of viral suspension on formvar coated grids. After $1 \mathrm{~min}$, the drop was blotted with filter paper and the sample examined by TEM.

Experimentally induced infection. Thirty turbot $(10$ to $20 \mathrm{~g}$ ) found to be free of eythrocytic virus, based on the study of blood smears stained with M-G, were used for experimental infections. Fish were maintained in seawater tanks at a temperature of 14 to $15^{\circ} \mathrm{C}$ and fed daily with commercial dry pellets throughout the experiment.

Twenty fish each received an intraperitoneal injection of tissue culture medium containing aproximately $10^{5} \mathrm{TCID}_{50}$ of the viral isolate. Ten control fish were injected with an equivalent volume of sterile saline. Between 2 and 3 wh later, the blood of infected and control fish were examined virologically and by light and electron microscopy.

Viral inoculation of an erythrocyte suspension. Blood was collected aseptically from healthy turbot following the procedure described above. After centrifugation at $400 \times g$ for $5 \mathrm{~min}$, erythrocytes were resuspended in Leibovitz' medium (L-15, Gibco) containing $5 \% \mathrm{FBS}$ and P/S. The erythrocyte suspension was adjusted to $10^{6}$ erythrocytes $\mathrm{ml}^{-1}$ using a haemocytometer. An aliquot of $500 \mu \mathrm{l}$ of this suspension was added to each well of a 24 well tissue culture plate, cooled to 4 or to $0^{\circ} \mathrm{C}$ in a cold chamber for 30 min then inoculated with the virus at a dose of approximately 100 infective units erythrocyte ${ }^{-1}$. Inoculate erythrocyte suspensions were kept for $30 \mathrm{~min}$ in the cold chamber with slow agitation, then warmed to $15^{\circ} \mathrm{C}$ and incubated for $0,1,3,5,10 \mathrm{~min}, 1,3,8 \mathrm{~h}, 1,2,3,4,5,6$ and $7 \mathrm{~d}$ at this temperature. After incubation, the erythrocytes were processed for observation with light and electron microscopy and for viral examination following the procedures described above. The same amount of virus-free medium was added to the erythrocytes used as controls. When cultures were kept for longer than $2 \mathrm{~d}, 300 \mu \mathrm{l}$ of the culture medium was removed and the same amount of fresh medium added.

In vitro replication in cultured turbot erythrocytes. A suspension of $10 \mathrm{ml}$ of turbot erythrocytes $\left(10^{7}\right.$ cells $\mathrm{ml}^{-1}$ ) in L-15 medium with $10 \% \mathrm{FBS}$ and $\mathrm{P} / \mathrm{S}$ (L$15 / 10 / \mathrm{Ab}$ ) was obtained as described above. A volume of $8 \mathrm{ml}$ of erythrocyte suspension was transferred to a new tube and inoculated with $1.3 \mathrm{ml}$ of crude virus $\left(5.6 \times 10^{7} \mathrm{TCID}_{50} \mathrm{ml}^{-1}\right)$. After a $30 \mathrm{~min}$ adsorption period at room temperature, erythrocytes were pelleted by centrifugation and the supernatant totally recovered and maintained at $-20^{\circ} \mathrm{C}$ for further titration of non-adsorbed virus. The cells were washed 3 


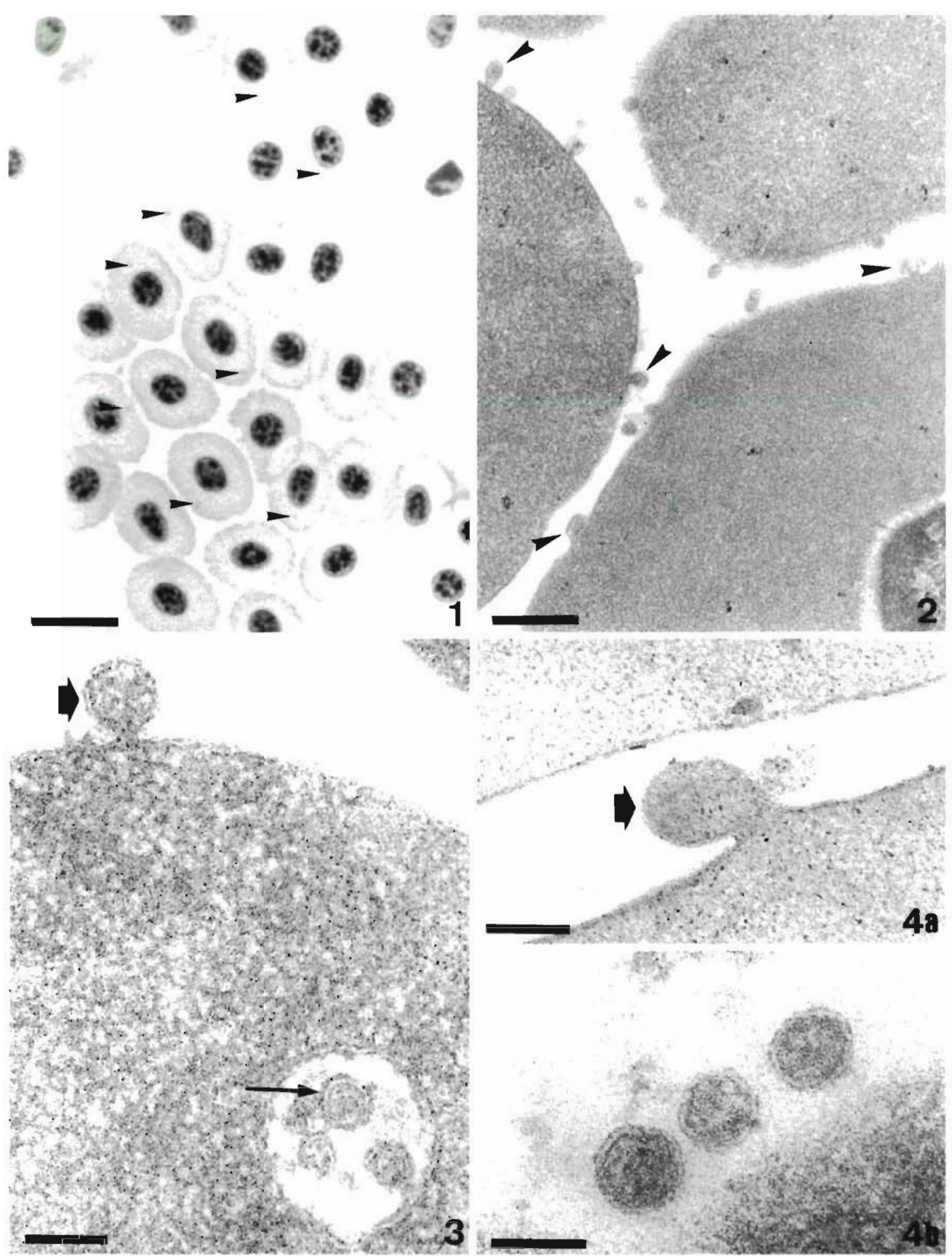

Figs. 1 to 4. Erythrocytic virus infection in Scophthalmus maximus Fig 1. Smear of peripheral blood showing several erythrocytes containing pale cytoplasmic inclusions (arrowheads) May-Grunwald-Giemsa. Scale bar $=10 \mu \mathrm{m}$ Fig 2 Electron micrograph of virus-like particles (arrowheads) at the erythrocyte membrane and extracellularly Scale bar $=300$ nm. Fig. 3. Virus-like partıcles within a vacuole (thin arrow) and at the erythrocyte membrane (thick arrow) Scale bar = $100 \mathrm{~nm}$ Fig. 4. (a) A virus-like particle is budding from the erythrocyte membrane (arrow), and (b) 3 virus-like particles located extracellularly Scale bars = 100 nm 
times with L-15/10/Ab and resuspended in $45 \mathrm{ml}$ of the same medium. A volume of $800 \mu$ l. of this suspension was transferred to a 48 well plate to yield about $10^{6}$ erythrocytes well ${ }^{-1}$, representing $0 \mathrm{~h}$ incubation. Six wells of the plate were covered with the same volume of non-inoculated erythrocytes, and used as controls. At different times $(0,1,2,3,4,5,6,7,8,9,10$, $24,36,48,60,72,84,96$ and $108 \mathrm{~h}$ ) the contents of the wells were totally recovered, centrifuged at $400 \times g$ for $5 \mathrm{~min}$ in a microcentrifuge (Eppendorf), and the supernatant transferred to new tubes maintained at $-20^{\circ} \mathrm{C}$ until titration of extracellular virus. Pelleted cells were resuspended in $300 \mu \mathrm{l}$ distilled water, subjected to 2 freezing-thawing cycles, and maintained at $-20^{\circ} \mathrm{C}$ until titration of intracellular virus. This assay was carried out in triplicate. At the end of the experiment, control erythrocytes were processed as described, and titration performed to rule out natural viral infection. Titration of virus was carried out according to the method of Reed \& Muench (1938), using 96 well plates of confluent EPC cells, and expressed as TCID $50 \mathrm{ml}^{-1}$.

\section{RESULTS}

\section{Examination of naturally infected turbot}

Naturally infected turbot had haemorrhages on the head, mouth and fins as well as exophthalmia. Additional signs were pale gills and liver but no haemorrhages were observed in the internal organs. Mortality observed in affected fish was about $10 \%$ and morbidity reached values up to $50 \%$.

The microbiological analysis revealed the presence in all stocks of affected turbot of a single-stranded RNA enveloped virus with a capsid containing between 6 and 10 proteins (Cepeda et al. 1993b). In addition, this virus proved to be pathogenic for fingerling turbot with a LD 50 of $10^{4} \mathrm{TCID}_{50} \mathrm{ml}^{-1}$ (Cepeda et al. 1993a).

Microscopic examination of blood smears revealed 1 to 3 inclusions in the cytoplasm of erythrocytes of all affected fish (Fig. 1). These inclusions were light blue in colour and ranged in size from 0.3 to $1 \mu \mathrm{m}$ in diameter, although the majority were smaller than $0.5 \mu \mathrm{m}$. Infected turbot had between 10 and $60 \%$ of their erythrocytes affected. However, due to the difficulty in observing these inclusions, the percentage of affected cells was probably higher.

Examination of blood cells by TEM showed oval to spherical virus-like particles located free or within double membraned vacuoles in the erythrocyte cytoplasm, at the cell membrane or extracellularly (Figs. 2, $3 \& 4$ ). The size of extracellular virus-like particles ranged from 50 to $160 \mathrm{~nm}$, although most of the parti-

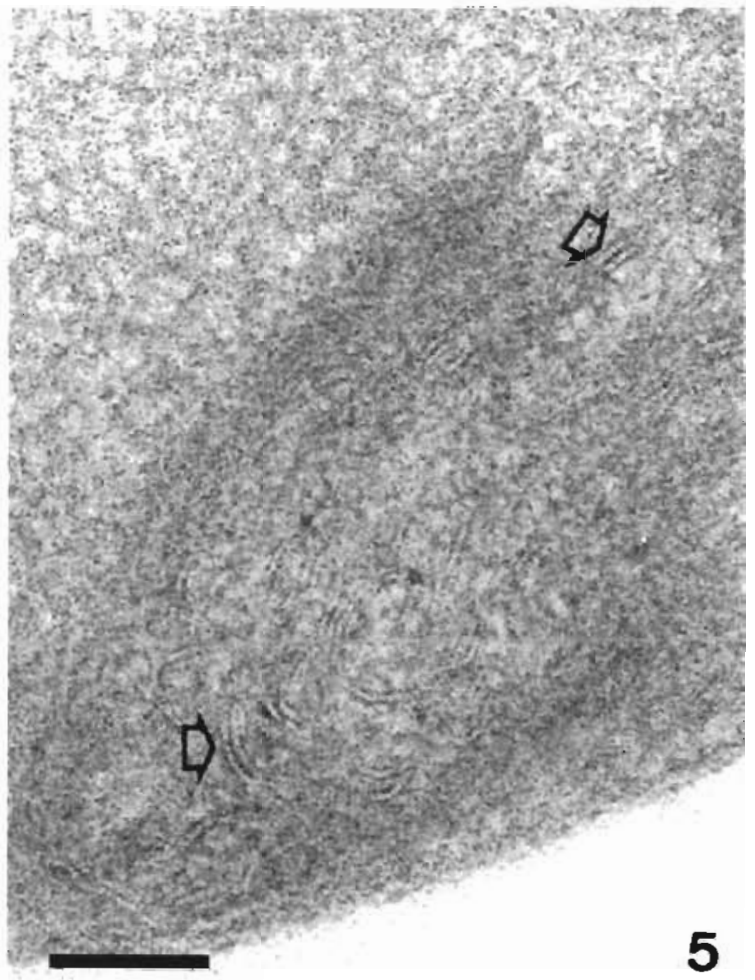

Fig. 5. Erythrocytic virus infection in Scophthalmus maximus. Cytoplasm of an infected erythrocyte from a naturally infected turbot showing a higher electron-dense area containing membranous-like structures. Scale bar $=100 \mathrm{~nm}$

cles measured between 80 and $110 \mathrm{~nm}$. Virus particles appeared to be assembled at the cell membrane followed by release from the erythrocyte by budding (Figs. $3 \& 4$ a). Sometimes, one or more virus-like particles appeared to be released from the same bud. Infected erythrocytes showed small cytoplasmic areas of higher electron-density showing membranous-like structures (Fig. 5).

\section{Infected EPC cell cultures}

In the EPC cultures, a clear cytopathic effect was detected between 6 to 15 d postinfection (Fig. 6) Rounding of infected cells followed by cell aggregation was observed between 3 to $6 \mathrm{~d}$, and cell lysis occurred from $6 \mathrm{~d}$ postinfection. Electron microscopy performed on EPC cell cultures at $6 \mathrm{~d}$ postinfection showed the presence of numerous virus-like particles in cytoplasmic vacuoles or at the cell membrane, apparently being released by budding (Figs. $7 \& 8$ ). The morphology and size of extracellular virus isolated from the EPC cell cultures was studied with TEM after negative staining. Examination of culture fluids revealed the 


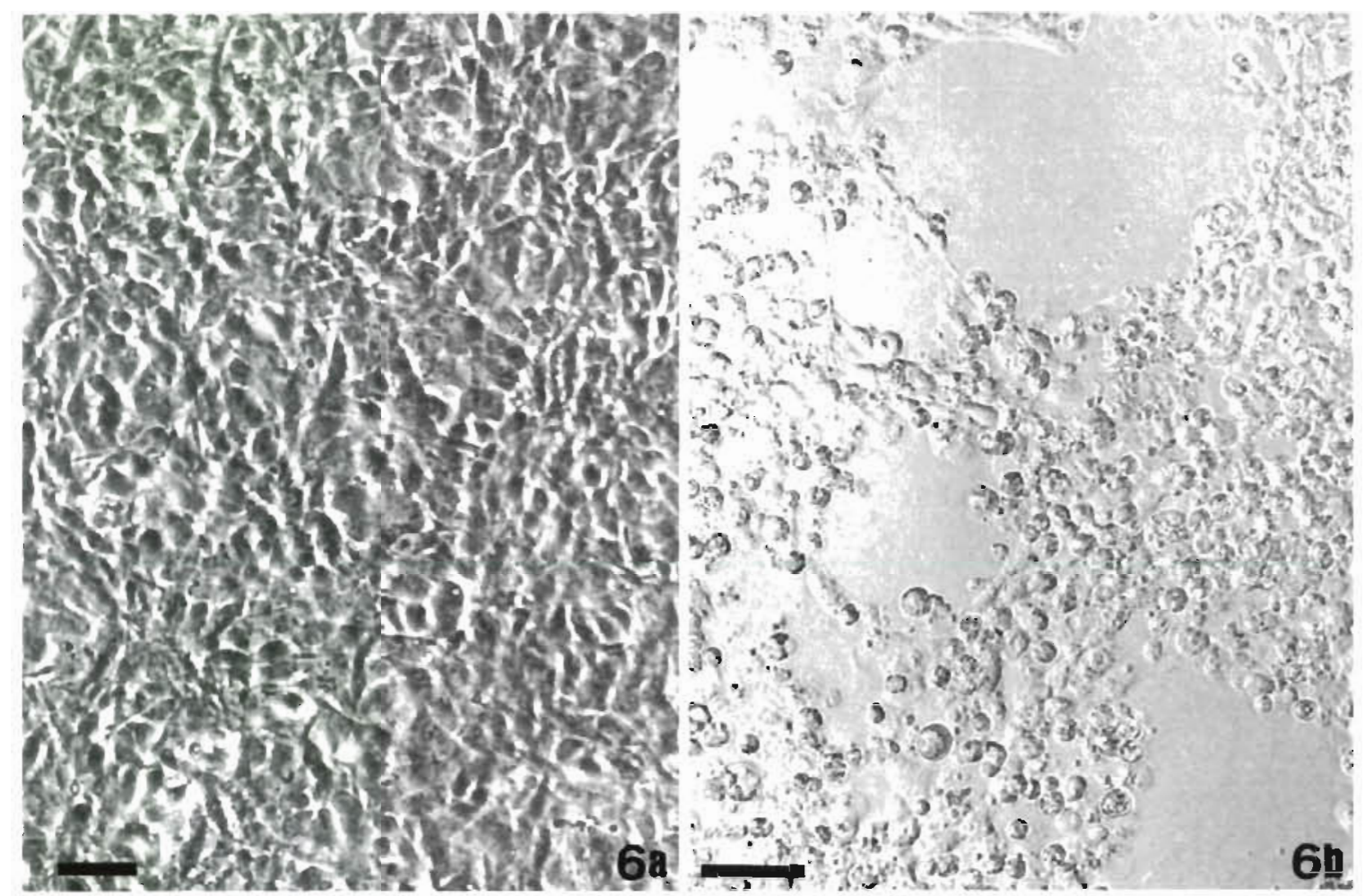

Fig. 6. (a) Control EPC cell cultures. (b) EPC cell cultures 6 d postinfection of virus. Phase contrast, scale bar $=50 \mu \mathrm{m}$

presence of virus-like particles highly variable in size (60 to $200 \mathrm{~nm}$ ) and showing small projections or spikes covering the envelope.

\section{Experimentally infected turbot}

Some fish infected experimentally with the isolated virus showed small petechiae in the fins and mouth 1 wk after inoculation. In the second week these petechiae became more evident, affecting the majority of the fish, and in the third week all fish developed haemorrhages in the mouth and fins, had pale gills and liver, and became moribund. The histopathology displayed by the fish infected experimentally was similar to that showed by naturally infected turbot (Lamas et al. 1995). Virus were recovered from spleen, kidney, liver and brain of all clinically diseased turbot and appeared to be the same virus which had been inoculated based on CPE. The viral titres ranged from $10^{6}$ to $10^{8} \mathrm{TCID}_{50} \mathrm{~g}^{-1}$ of tissue. At 3 wk the prevalence of infection was $100 \%$ with 10 to $30 \%$ of erythrocytes showing cytoplasmic inclusions.

Turbot used as controls remained normal. Virus was not isolated from these fish and inclusions or virus particles were not observed in the circulating erythrocytes.

\section{Study of erythrocyte cultures}

Morphology of control erythrocytes

The erythrocytes used as a control showed an apparently normal morphology throughout the experiment, although a very small number became pycnotic. The organelles observed in the cytoplasm of turbot erythrocytes were variable and probably related to the state of cell maturation. Therefore, circulating erythrocytes showed a variable degree of maturation. Some cells, probably the most immature, had a few mitochondria abundant ribosomes and polyribosomes as well as occasional cisterns of endoplasmic reticulum or reduced Golgi apparatus. Vesicles ranging in size from 50 to $300 \mathrm{~nm}$ in diameter were also common. In the most mature cells these organelles were absent and only a few scattered ribosomes were observed.

\section{Erythrocytes exposed to cultured virus}

Inoculated virus did infect turbot erythrocytes in vitro. This was most commonly observed in the immature cells. Virus-like particles were observed within cytoplasmic vacuoles at $0 \mathrm{~min}$ when the erythracyte 

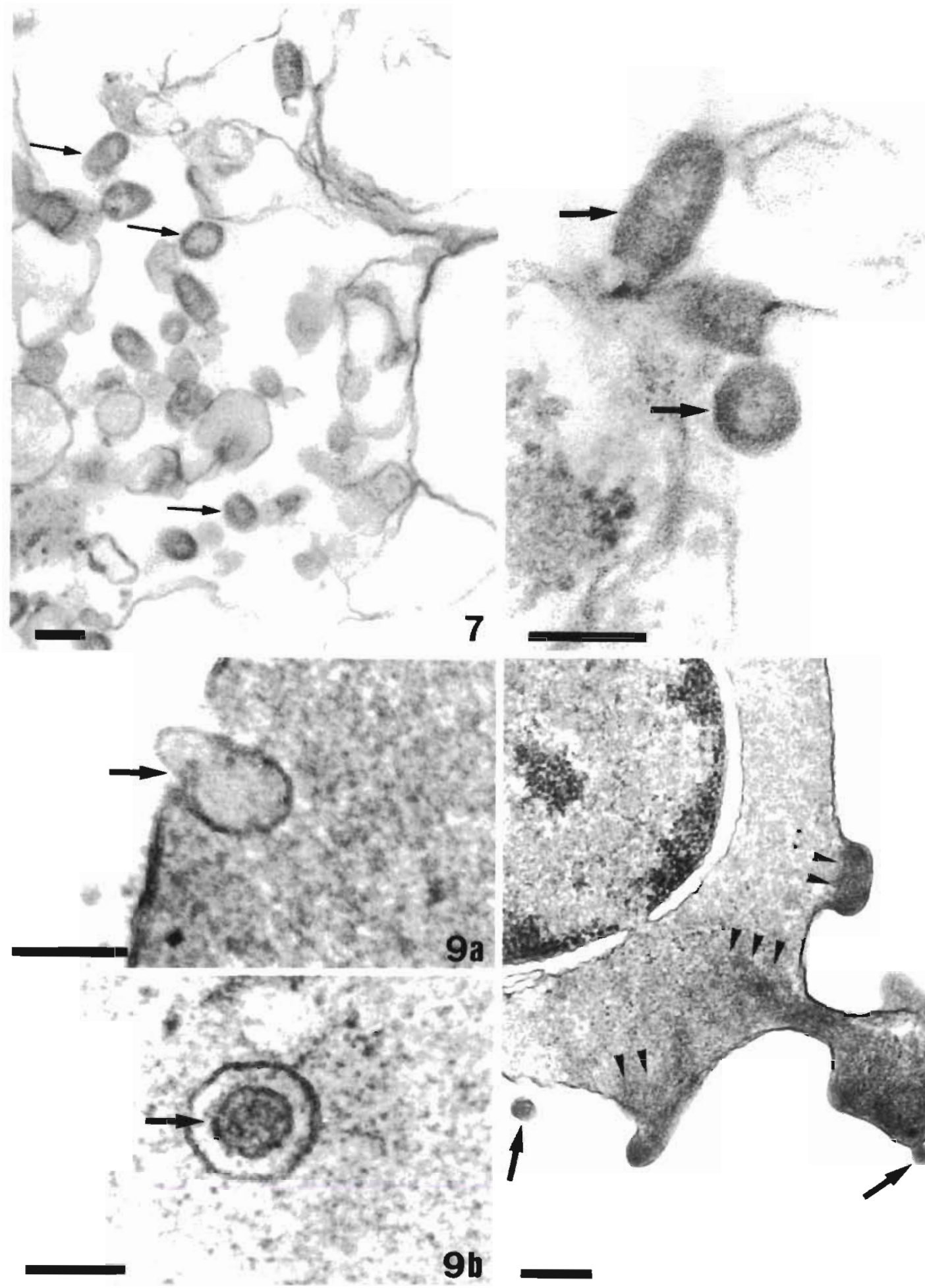

8

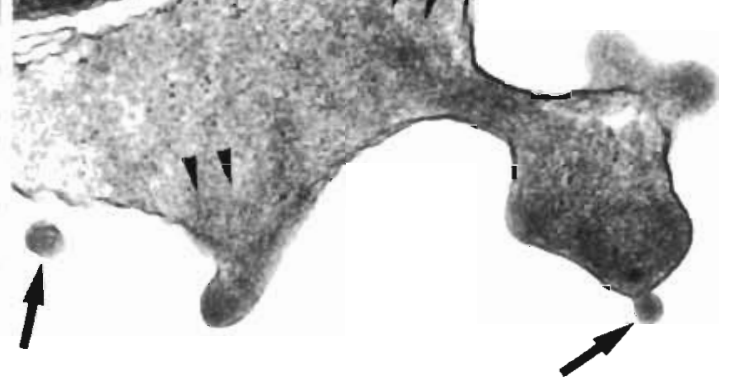

9b

10

Figs. 7 to 10. Fig. 7 . Electron micrograph of numerous virus-like particles (arrows) being released from a EPC cell 6 d postinfection. Scale bar $=100 \mathrm{~nm}$. Fig. 8. Virus-like particles budding from a EPC cell 6 d postinfection TEM. Scale bar $=100 \mathrm{~nm}$. Fig. 9 . (a) Viruslike particle (arrow) penetrating in the erythrocyte, 5 min postinfection. (b) Virus-like particle within a cytoplasmic vacuole (arrow) at $3 \mathrm{~min}$ postinfection. TEM; scale bars $=100 \mathrm{~nm}$. Fig. 10. Virus-like particles (arrows) being released from the erythrocyte at $6 \mathrm{~d}$ postinfection. Note the presence of high electron-dense areas in the cytoplasm of the erythrocyte (arrowheads). The density is higher in the large viral buds. Scale bar $=300 \mathrm{~nm}$ 
suspensions were preincubated with the virus at $4^{\circ} \mathrm{C}$, but no internal virus-like particles were observed at this time in cells preincubated with the virus at $0^{\circ} \mathrm{C}$.

After incubation for $5 \mathrm{~min}$ at $15^{\circ} \mathrm{C}$, virus-like particles were observed adsorbed to the cell membrane or within small cytoplasmic vesicles near the erythrocyte surface (Fig. 9). Usually only 1 virus particle was present in each vesicle. With longer incubations, vesicles were larger and contained more virus. After $1 \mathrm{~h}$ incubation, virus-like particles were also visible in larger smoothsurfaced vacuoles which may be endosomes. Virus-like particles were often bound to the vacuolar membrane and sometimes the viral envelope seemed to fuse with the vacuolar membrane. In addition, some virus-like particles seemed to be undergoing uncoating inside the vacuoles. After 2 to $3 \mathrm{~d}$, occasional eythrocytes showed irregular morphology with numerous large external cytoplasmic buds; after $6 \mathrm{~d}$ many more erythrocytes displayed this irregular shape. These erythrocytes showed electron-dense cytoplasmic areas which were especially evident in the cytoplasmic buds (Fig. 10). Virus-like particles, highly variable in size, were released by budding from these buds or from adjacent areas (Fig. 10). The cell nucleus was usually unaffected.

In vitro replication in turbot erythrocytes

Viral titres of inoculum and non-adsorbed virus are shown in Table 1 . The difference between total viral titres of inoculated and non-adsorbed virus $\left(2.1 \times 10^{7}\right.$ $\mathrm{TCID}_{50}$ ) corresponds to the quantity of adsorbed virus. Thus, the quantity of virus obtained at time zero of the in vitro replication experiment should be $3.7 \times 10^{5}$ $\mathrm{TCID}_{50}$ well $^{-1}$ However, the total viral titre at time zero was $2.13 \times 10^{4} \mathrm{TCID}_{50}$ well $^{-1}$. The difference could be due to non-adsorbed erythrocyte-associated virus being washed out after the adsorption period.

The results obtained in the replication experiment (expressed as average values from 3 separate wells) are presented in Fig. 11 As shown, the intracellular titre remained relatively constant throughout the experiment, with an average value of $3.696 \pm 0.394$. However, extracellular virus showed a clear increase

Table 1. Viral titres of inoculum, non-adsorbed virus and virus at time zero (intracellular plus extracellular virus at $0 \mathrm{~h}$ ). - : not applicable

\begin{tabular}{|lccc|}
\hline & $\begin{array}{c}\text { Viral titre } \\
\left.\text { (TCID }_{50} \mathrm{ml}^{-1}\right)\end{array}$ & $\begin{array}{c}\text { Volume } \\
(\mathrm{ml})\end{array}$ & $\begin{array}{c}\text { Total viral titre } \\
\text { (TCID }_{50} \text { /total volume) }\end{array}$ \\
\hline Inoculated virus & $5.6 \times 10^{7}$ & 1.3 & $7.3 \times 10^{7}$ \\
Non-adsorbed virus & $5.6 \times 10^{6}$ & 9.3 & $5.2 \times 10^{7}$ \\
Virus at time zero & - & - & $2.13 \times 10^{4}$ \\
\hline
\end{tabular}

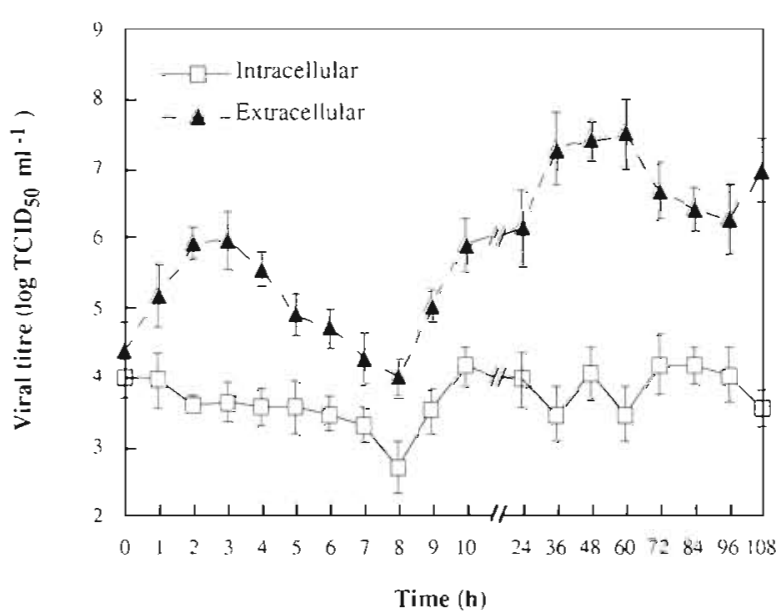

Fig. 11. Erythrocytic virus infection in Scophthalmus maximus. Extra- and intracellular virus titres obtained from in vitro infected erythrocyte cultures. Cell culture medium and cells were collected at several time intervals and assayed in EPC cells

of titre from the first hours of the assay, reaching maximum values at between 36 and $60 \mathrm{~h}$ postinfection, representing an increase of viral titre of more than 3 logs.

\section{DISCUSSION}

The rapid development of turbot culture in recent years has resulted in the frequent appearance of new bacterial and viral diseases. Currently, the viruses described in turbot have been identified as members of the Picornavirus, Birnavirus, Reovirus, Rhabdovirus and presumptive Paramyxovirus groups (Toranzo et al. 1994). Although the incidence of the viral erythrocytic infection in turbot farms in Galicia is still under study, it seems to be of considerable importance. In addition to the 3 affected fish farms cited in the present paper, new cases have recently been discovered causing large mortalities in cultured turbot.

The overall findings reported in this study clearly demonstrated that the virus-like particles observed in the erythrocytes of naturally infected turbot and the virus isolated in the EPC cell line (Cepeda et al. 1993b) from the internal organs of the same fish were the same virus. We have found fish erythrocytes especially valuable for the in vitro study of erythrocytic viruses. Erythrocytes can be maintained in culture for at least $7 \mathrm{~d}$ without apparent morphological alterations, except for the loss of occasional erythrocytes which were probably senescent. Although the time required for the maturation of turbot erythrocytes is 
not known, other fish species such as goldfish and rainbow trout have circulating erythrocytes requiring 16 to 21 and 40 d for maturation, respectively (Härdig 1978, Murad \& Houston 1992). As shown in previous studies the maturation of erythrocytes can be estimated by the number of cytoplasmic organelles which decrease with age, the adult erythrocyte being devoid of mitochondria and polyribosomes (Lane et al. 1982). Lane et al. (1982), using a velocity sedimentation gradient at unit gravity, showed that $28 \%$ of circulating rainbow trout erythrocytes contained cytoplasmic organelles. Our ultrastructural studies indicated that turbot virus mainly penetrates immature erythrocytes. However, electron microscopy did not allow the assessment of the percentage of immature versus infected erythrocytes with any degree of certainty.

Virus-like particles appear to be adsorbed and endocytosed as the principal way of penetration of the virus into the erythrocyte. In the early stages of infection $(<5$ min) virus-like particles were observed in small vesicles, suggesting that entry was very rapid. The absence of intracellular virus particles after preincubation for $30 \mathrm{~min}$ at $0^{\circ} \mathrm{C}$ may be due to low temperatures, which are very effective inhibitors of endocytosis (Steinman et al. 1983). The entry occurred, however, at $4^{\circ} \mathrm{C}$ suggesting that this process does not require or requires very low metabolic activity. Whether the process of endocytosis is receptor mediated is still unknown.

The greater presence of virus in immature erythrocytes may be related to a higher level of endocytic activity observed in these cells, in contrast to more mature erythrocytes. On the other hand, the entrance of virus particles into immature erythrocytes may favor virus replication by use of cell organelles like ribosomes. In later stages, virus particles were also observed in intracellular vacuoles. Whether these vacuoles are endosomes or lysosomes is still unknown. The envelope of viral particles apparently fused with the endosome membrane suggesting that the uncoating process occurs at this level. The presence of high electron-dense areas located in the cytoplasm of infected erythrocytes may be related to accumules of viral components. Finally, the envelope of the virus appeared to be assembled at the cell-surface membrane, where the virus is released by budding. When release is in progress, large buds appeared on the surface of the cells which seemed to become segmented into smaller units of variable sizes. At this level, virus particles were pleomorphic, probably as a consequence of the conformation of the nucleocapsid and of the flexibility of the envelope. However, extracellular virus particles tended to be ovoid or spherical, which is probably the more stable conformation.

The results obtained in the replication experiments indicate that the virus-like particles are capable of replicating within the erythrocytes confirming the results of TEM. The intracellular viral titre remained constant for a period of $5 \mathrm{~d}$ after erythrocyte infection. However, the extracellular viral titre increased with time reaching a maximun at between 36 and $60 \mathrm{~h}$ postinfection. These results seem to indicate that the virus needs to be released extracellularly to be infective, which is probably a consequence of the fact that budding is necessary for maturation as this is an enveloped virus.

The size and characteristics of the virus described in this study are clearly different from those associated with other fish erythrocytic infections such as VEN and EIBS. The particles described here were characterized as an RNA virus (Cepeda et al. 1993b), similar to that described by Pintó et al. (1991) in sea bass and to the virus described by Hedrick et al. (1990) in coho salmon, as well as to that described in infectious salmon anaemia (Hovland et al. 1994, Nylund et al. 1995). However, unlike those viruses the turbot virus had a wider variation of sizes. Also, the previous authors did not observe budding of virus particles in the extracellular medium, with the exception of the virus which caused infectious salmon anaemia, and they were unable to culture the viruses using salmonid cell lines.

The erythrocytic virus caused moderate anaemia in sea bass (Pintó \& Alvarez-Pellitero 1993) and the infectious salmon anaemia virus caused intense anaemia in salmon (Thorud \& Djupvik 1988). Some of the naturally infected turbot showed an intense erythroblastosis in the blood but, in contrast, the haematocrit values were not much different from those in healthy turbot (Lamas et al. 1995). Unlike the infectious salmon anaemia virus, whose primary target cell seems to be the vascular endothelium, the turbot virus seems to infect mainly erythrocytes.

Although the virus described in this study was identified presumptively as a paramyxovirus (Cepeda et al. $1993 \mathrm{a}, \mathrm{b}$ ), this virus probably belongs to another virus family. It resembles paramyxoviruses in the presence of spikes, the assembly of the virus envelope at the level of the cell membrane and the pleomorphism. However, it differs from conventional paramyxoviruses in size and in the way it penetrates the host cell. Paramyxoviruses penetrate by fusion of their envelopes with the plasma membrane and have a size of 150 to $300 \mathrm{~nm}$ in diameter (Ginsberg 1988). In addition, we have recently found that this viral agent is inhibited by Actinomycin-D, but not by trypsin treatment and lacks haemagglutinating capacity against fish and mammalian erythrocytes (Cepeda 1994). Unfortunately, we are having many difficulties with the extraction of the nucleic acid from the virus. This is one reason we cannot not group this agent. However, these 
discrepancies suggest that the erythrocytic turbot virus is not a paramyxovirus but rather belongs to another viral group which has not been determined to date.

Acknowledgements. This study was supported by grants awarded by the Comision Interministerial de Ciencia y Tecnologia (ClCYT) no. AGF93-0769-C0201 and by the EUREKA project no. EU-347, between Spann and Norway. The authors thank Dr Christine Francis for her critical reading of the manuscript.

\section{LITERATURE CITED}

Appy RG, Burt MDB, Morris TJ (1976) Viral nature of piscine erythrocytic necrosis (PEN) in the blood of Atlantic cod (Gadus morhua). J Fish Res Bd Can 33:1380-1385

Arakawa CA, Hursh DA, Lannan CN, Rohovec JS, Winton JR (1989) Preliminary characterization of a virus causing infectious anemia among the stocks of salmonid fish in the western United States. In: Ahne W, Kurstak E (eds) viruses of lower vertebrates. Springer-Verlag, Berlin, p $442-450$

Cipeda C (1994) Caracterización e identificación de un nuevo patógeno viral para rodaballo. MSc thesis, University of Santiago de Compostela

Cepeda C, Rivas C, Lamas J, Ledo A, Dopazo CP, Toranzo AE (1993a) Patogenucidad de un nuevo agente viral (Paramyxovirus) aislado de rodaballo. In: Cerviño $A$, Landín A, Coo A, Guerra A, Torre M (eds) Actas IV Congreso Nac Acuicult, llla de Arousa, Pontevedra, Spain, p 651-655

Cepeda C, Rivas C, Ledo A, Dopazo CP, Barja JL, Toranzo AE (1993b) First isolation of a presumptive Paramyxovirus from turbot. In: Abstracts of the IXth internat Cong Virol, Glasgow, p 201

Evelyn TPT, Traxler GS (1978) Viral erythrocytic necrosis: natural occurrence in Pacific salmon and experimental transmission. J Fish Res Bd Can 35:903-907

Foot JS, Miller A, Steiner R, Hedrick RP (1992) Erythrocytic inclusion body syndrome (EIBS) infection of chinook salmon in ldaho. J aquat Anım. Health 4:306-308

Ginsberg HS (1988) Paramyxoviruses. In: Dulbecco R, Ginsberg HS (eds) Virology. JB Lippincott Company, Philadelphia, p 239-259

Härdig J (1978) Maturation of circulating red blood cells in young Baltic salmon (Salmo salar L.). Acta Physiol Scand 102:290-300

Hedrick RP, McDowell T, Groff JM (1990) Virus-like particles in erythrocytes of coho salmon (Oncorhynchus kisutch). Aquaculture 89:377-381

Hovland I. Wylund A, Watanabe K, Endresen C (1994) Observation of infectious salmon anemia virus in Atlantic salmon, Salmo salar L. J Fish Dis 17:291-296

Lamas J, Noya M, Figueras A, Toranzo AE (1995) Pathology associated with a viral erythrocytic infection in turbot, Scophthalmus maximus (L.). J Fish Dis 18:425-433

Lane HC, Weaver JW, Benson JA, Nichols HA (1982) Some age related changes of adult rainbow trout, Salmo gairdneri Rich., peripheral erythrocytes separated by velocity sedimentation at unit gravity. J Fish Biol 21:1-13

Leek SL (1987) Viral erythrocytic inclusion body syndrome (EIBS) occurring in juvenile spring chinook salmon

Responsible Subject Editor: F. M. Hetrick, College Park, Maryland, USA
Oncorhynchus tshawytscha) reared in freshwater Can J Fish Aquat Scl 44:685-688

Lunder T, Thorund K, Poppe TT, Holt RA, Rohovec JS (1990) Particles simular to the virus of erythrocytic inclusion body syndrome, EIBS, detected in Atlantic salmon (Salmo salar) in Norway. Bull Eur Ass Fish Pathol 10:21-23

Meyers TR, Hauck AK, Blankenbeckler WD, Minıcucci T (1986) First report of a viral erythrocytic necrosis in Alaska, USA, associated with epizootıc mortality in Pacific herring, Clupea harengus pallası (Valenciennes). J Fish Dis 9:479-491

Murad A, Houston AH (1992) Maturation of the goldfish (Carassius auratus) erythrocyte. Comp Biochem Physıl $102: 107-110$

Nylund A, Hovland T, Watanabe K, Endresen C (1995) Presence of infectious salmon anaemia virus (ISAV) in tissues of Atlantic salmon, Salmo salar L., collected during three separate outbreaks of the disease. J Fish Dis 18:135-145

Piacentini SC, Rohovec JS, Fryer JL (1989) Epizootiology of erythrocytic inclusion body syndrome. J aquat Anum Health 1:173-179

Pilcher KS, Fryer JL (1980) The viral diseases of fish: a review through 1978. Part II. Diseases in which the viral etiology is suspected but unproven. CRC Crit Rev Microbiol 8:1-25

Pintó RM. Alvarez-Pellitero P (1993) Development and physiological effects of viral erythrocytic infection (VEI) in naturally-infected cultured sea bass. Aquaculture 115 : 221-232

Pinto RM, Alvarez-Pellitero P, Bosch A, Jotre J (1989) Occurrence of a viral erythrocytic infection in the Mediterranean sea bass, Dicentrarchus labrax (L.). J Fish Dis 12: $185-191$

Pintó RM, Jofre J, Bosh A (1991) Viral erythrocytic infection in sea bass: virus purification and confirmative diagnosis. Arch Virol 120:83-96

Reed LJ, Müench H (1938) A simple method of estimating fifty percent endpoints. Am J Hyg 27:493-497

Reno PW, Philippon-Fried M, Nicholson BL, Sherburne SW (1978) Ultrastructural studies of piscine erythrocytic necrosis (PEN) in Atlantic herring (Clupea harengus harengus). J Fish Res Bd Can 35:148-154

Smail DA, Egglestone Sl (1980) Virus infections of marine fish erythrocytes: prevalence of piscine erythrocytic necrosis in cod Gadus morhua L. and blenny Blennius pholis L. in coastal and offshore waters of the United Kingdom. J Fish Dis 3:41-46

Steinman RM, Mellman IS, Muller WA, Cohn ZA (1983) Endocytosis and the recycling of plasma membrane. J Cell Biol 96:1-27

Takahashi K, Okamoto N, Kumagai A, Maita M, Ikeda Y, Rohovec JS (1992) Epizootics of erythrocytic inclusion body syndrome in coho salmon cultured in seawater in Japan. J aquat Anim Health 4:174-181

Thoesen JC (1994) Suggested procedures for the detection and identification of certain finfish and shellfish pathogens, 4 th edn. Fish Health Section, American Fisheries Society, Maryland

Thorud K, Djupvik H O (1988) Infectious anaemia in Atlantic salmon (Salmo salar L.). Bull Eur Ass Fish Pathol 8: $109-111$

Toranzo AE, Barja JL, Devesa S (1994) An overview of the main infectious problems in cultured turbot: present status and future necessities. In: Lavens P, Remmerswall R (eds) Turbot culture: problems and prospects. Eur Aquacult SoC Special Publication No 22, Gent, p 106-126 